\title{
METHODS FOR DETERMINING THE CHARACTERIZATION OF MASHES WITH FIBER FOR SEMI-FINISHED PRODUCTS ON THE MILK-PROTEIN BASE
}

\author{
Olena Grek \\ grek.nupt@gmail.com \\ Alla Tymchuk ${ }^{1}$ \\ 589112@ukr.net \\ Sergii Tsygankov \\ Institute of Food Biotechnology and Genomics NAS of Ukraine \\ $2 A$ Osypovskoho str., Kyiv, Ukraine, 04123 \\ tsygankov.iht@gmail.com \\ Olena Onopriichuk ${ }^{1}$ \\ olena.onopriychuk@gmail.com \\ Oleksandr Savchenko ${ }^{2}$ \\ 63savchenko@gmail.com \\ Olena Ochkolyas \\ lenokochkolyas@gmail.com \\ ${ }^{1}$ Department of milk and dairy products technology \\ National University of Food Technologies \\ 68 Volodymyrska str., Kyiv, Ukraine, 03680 \\ ${ }^{2}$ Department of technologies of meat, fish and marine products \\ National University of Life and Environmental Sciences of Ukraine \\ 15 Heroiv Oborony str., Kyiv, Ukraine, 03041
}

\footnotetext{
Abstract

The aim of the work is to elaborate effective methods that characterize mashes of semi-products with potato fiber after thermal processing for avoiding excessive densification of products and stabilization of qualimetric parameters.

The article presents main methods for determining characteristics of mashes with potato fiber for thermally processed semi-products.

Methods for studying the ability of dietary fiber «Potex» to change the effective viscosity and water-retaining capacity of multicomponent systems are offered. Values that characterize deviations of parameters at using white sugar the dehydrating capacity and egg mélange, which influence is changed by the aforesaid parameters at thermal processing, are obtained.

The effectiveness of determining the water activity value aw for specifying storage parameters of mashes with potato fiber for semi-products is confirmed.

Qualimetric parameters of experimental samples are obtained. Least mass losses at frying $\left(155 \pm 5^{\circ} \mathrm{C}\right)$ and baking $\left(185 \pm 5^{\circ} \mathrm{C}\right)$ were observed at adding maximal amount of «Potex» $(2.0 \%)$ and fixed at level $4.3 \pm 0.2 \%$ and $6.2 \pm 0.1 \%$ respectively. Introduction of dietary fiber decreases a content of free water in mashes for semi-products and, as a result, there is observed a mass loss decrease at thermal processing. It allows to stabilize qualimetric parameters.
}

Keywords: potato fiber, water activity, water-retaining capacity, effective viscosity, thermal processing.

DOI: $10.21303 / 2504-5695.2019 .001046$

\section{Introduction}

A search for new biocorrectors of different functional directionalities of accessible and relatively cheap raw materials, elaboration of technologies of food products with such supplements and study of their consumption properties are an urgent task of milk industry. 
Semi-products on the milk-protein base are products of sour-milk cheese in a dough tunic or pancake sheet with adding flour and other food products. Such products need further thermal processing (frying, boiling, heating or baking) [1]. A mass of recipe components after the mechanical processing (mixing) is called a mash.

For baking semi-products, based on milk-protein concentrates (MPC), there are used heating chambers of different constructions with low or upper heating, natural or forced circulation of hot air or overheated water steam. One-portion semi-products, such as casserole, are thermally processed at temperature $180 \ldots 250{ }^{\circ} \mathrm{C}$ up to $30 \mathrm{~min}[2,3]$.

Frying of semi-products, based on milk-protein concentrates with small amount of fat (5...8\% of the product mass) is dry heating, where the surface of products contacts with fat, heated to $150 \ldots 160^{\circ} \mathrm{C}$ [4]. All types of thermal processing change qualimetric parameters of semi-products. A change of recipe components of traditional products (wheat flour for dietary fiber) needs additional determinations for risks minimization.

The intensity and development type of microbiological processes depends on content and properties of products, their initial insemination and also moisture content, water activity, $\mathrm{pH}$ and other [5]. Methods for water activity determination are expedient to use for specifying storage regimes of semi-products, based on sour-milk cheese with limited storage terms at standard temperatures.

The use of potato fiber (PF) instead of wheat flour in the technology of thermally processed semi-product, based on sour-milk cheese for decreasing a caloric value and improving quality parameters of products and also as a functional ingredient is expedient [6].

Potato fiber «Potex» («Lyckeby Culinar», Sweden) - is a product of processing of vegetable raw materials that has in its composition a wide spectrum of substances of the functional directionality (dietary fiber, pectin substances, cellulose, vitamins, minerals and so on.) [7]. According to literary data $[8,9]$, PF is characterized by high contents of macro- and microelements, such as potassium and phosphorus. According to producer's data, the content of dietary fiber in «Potex» is $65 \mathrm{~g} / 100 \mathrm{~g}$ of the product. Potato fiber is a competitive ingredient in many products of meat-processing, bakery and confectionary branches that is confirmed by correspondent researches $[10,11]$.

There is a production practice of using «Potex» in recipes of meat-vegetable semi-products for stabilizing structural-mechanical properties of products, improving formation processes, decreasing moisture losses at a thermal influence [12]. Water-binding properties of dietary fibers were fixed in fermented milk beverages, spreads, cheese products. The analysis of correspondent studies [13-15] confirms the topicality of this problem. The results and comparative estimation are given mainly using organoleptic research methods. The use of methods that allows to determine the mechanism of the influence of dietary fiber on properties of mashes on the milk-protein base needs additional studies.

The aim of the work is to elaborate effective methods that characterize mashes of semi-products with potato fiber after thermal processing for avoiding excessive densification of products and stabilization of qualimetric parameters before and after thermal processing.

\section{Materials and Methods}

At the first stage of experimental studies there were made experimental samples of milk-protein mashes (MPM) of the following composition: sour-milk cheese (from $74 \%$ to $78.0 \%$ ), potato fiber (PF) (from $0.5 \%$ to $2.0 \%$ ), white sugar (10\%), egg melange (10\%). Wheat flour (6.0\%) was used as a control sample instead of PF and all aforesaid ingredients.

Fatless sour-milk cheese (FLSMC) had the following parameters: mass share of moisture $(76.0 \pm 2.0) \%$, protein $-(18.0 \pm 1.1) \%$, lactose $-(1.8 \pm 0.8) \%$ and titrated acidity $-(204.0 \pm 2.2)^{\circ} \mathrm{T}$.

Potato fiber «Potex» had the following composition, in \%: mass share of moisture - 9.0 ; protein - 5.0; mineral substances (ash) - 4.0; fat (including saturated) - $0.3(0.06)$; carbohydrates (including starch) -17.0 (12.0). The content of fiber in PF is $65.0 \%$, pectin and hemicellulose $-47.0 \%$, cellulose $23.0 \%$, phosphorus and potassium, in $\mathrm{mg} / 100 \mathrm{~g}$, is 60.0 and 1200.0 respectively. The energetic (caloric) value for $100 \mathrm{~g}$ of the product is $905 \mathrm{~kJ}(221 \mathrm{kcal})$ [6]. 
According to producer's recommendations [9], the amount of PF for semi-products, subjected to thermal processing, is $0.5 \ldots 1.5 \%$ for frying. Diapasons of adding dietary fiber (DF) were spread for increasing functionality of semi-products.

White sugar with mass share moisture $(0.2 \pm 0.1) \%$, carbohydrates $-(99.8 \pm 0.1) \%$ and egg mélange in amount $10 \%$ were also used in mashes. These ingredients are classic in mashes, so used in the fixed amounts.

The chemical composition of egg mélange is presented in Table 1 [16].

Table 1

The chemical composition of egg mélange

\begin{tabular}{cc}
\hline Composition & Mass share, \% \\
\hline moisture/protein substances/fat & $75.6 \pm 0.1 / 12.22 \pm 0.2 / 9.71 \pm 0.3$
\end{tabular}

Wheat flour, used for the control sample, had the following physical-chemical indices: mass share of fat $-(1.1 \pm 0.1) \%$, protein $-(10.3 \pm 0.1) \%$, carbohydrates $-(70.0 \pm 0.3) \%$. Energetic (caloric) value for $100 \mathrm{~g}$ of the product is $1396.12 \mathrm{~kJ}(334.0 \mathrm{kcal})$.

MPM were prepared as following. Sour-milk cheese was processed by rollers if necessary before use (for giving the homogenous consistence). The recipe components (white sugar and wheat flour) were sieved. The process of mixing all components with adding PF (for experimental samples) and egg mélange was realized during $4 \ldots 8 \mathrm{~min}$. Recipe variants of MPM are presented in Table 2.

Table 2

Recipe variants of milk-protein mashes

\begin{tabular}{cccccc}
\hline \multirow{2}{*}{ No. of sample } & \multicolumn{4}{c}{ Amount of recipe components in model samples, \% } \\
\cline { 2 - 5 } & Fatless sour-milk cheese & White cheese & PF & Wheat flour & Egg mélange \\
\hline 1 (control) & 74.0 & & - & 6.0 \\
2 & 79.5 & 10 & 0.5 & - & 10 \\
3 & 79.0 & & 1.0 & - & - \\
4 & 78.5 & 1.5 & 2.0 & -
\end{tabular}

Then there were determined the water-retaining capacity, titrated acidity, effective viscosity, and water activity. Then the mashes were directed to the thermal processing for determining qualimetric parameters.

The water-retaining capacity (WRC) of MPM was determined by the gravimetric method by Grau-Hamm in A. Alekseev's modification [17]. A filter was placed on a glass plate with size $11 \times 11 \times 0.5 \mathrm{~cm} .0 .3 \mathrm{~g}$ of the milk-protein mash was weighed with the distinctness up to $0.5 \mathrm{mg}$ and transferred on a polyethylene film with diameter $40 \mathrm{~mm}$. The film was covered from above by the glass plate of the same size, and a load with mass $0.5 \mathrm{~kg}$ is put on it. The content was pressed during $7 \mathrm{~min}$. After that the filter with MPM is released from the load and plate. MPM together with the polyethylene film was taken away from filtering paper and weighed. A mass difference of the product with the film before and after processing indicates the mass of released whey. The number of moisture, retained by the sample, was determined by the formula:

$$
\mathrm{WRC}=100(a-b) / a,
$$

where WRC - water-retaining capacity of MPM, \%; $a$ - moisture amount in the batch, mg; $b-$ whey amount, separated from MPM, mg. 
where 300 - MPM batch, mg; Msol - moisture mass share in MPM, \% [18].

The titrated acidity of MPM was determined by the following way. $5 \mathrm{~g}$ of MPM was put in a porcelain pounder of $150 \ldots 200 \mathrm{~cm}^{3}$, accurately mixed and rubbed, $50 \mathrm{~cm}^{3}$ of water with temperature $35 \ldots 40{ }^{\circ} \mathrm{C}$ was added by small shares, three drops of phenolphthalein solution. They were titrated by the solution of sodium hydroxide $(\mathrm{NaOH}$ and $\mathrm{KOH})$ to the light pink coloration that doesn't disappear during $1 \mathrm{~min}$. The acidity, ${ }^{\circ} \mathrm{T}$, equals to amount of milliliters $0.1 \mathrm{n}$ solution of $\mathrm{NaOH}$, spent for neutralization of $5 \mathrm{~g}$ of the product, multiplied by 20 . The difference between parallel calculations must not exceed $4^{\circ} \mathrm{T}[17]$.

Rheological parameters of MPM were determined by the rotation viscosimeter «Reotest II» (MLW, Germany) with a measuring system cylinder-cylinder by fixing curves of deformation (flow) kinetics [19, 20]. The measurement was realized in the mode "a", experimentally fixed, taking into account structural-mechanical properties of the studied samples. The shift tension $\tau(\mathrm{Pa})$ was measured at twelve values of the shift speed gradient $\gamma$ in the diapason from 0.33 to $145.8 \mathrm{~s}^{-1}$ at the straight stroke, for that indications of the value $\alpha$ were fixed at the minimal deviation angle of an arrow on the device scale. The shift tension $(\mathrm{Pa})$ was calculated by the formula:

$$
\tau=Z \cdot \alpha
$$

where $Z$ - cylinder constant, Pa.un. of the scale; $\alpha$-indications of the device measuring scale.

The effective viscosity $(\mathrm{Pa} \cdot \mathrm{s})$ was calculated by the formula:

$$
\eta_{e f}=\frac{\tau}{\gamma}, \text { ef, }
$$

where $\gamma$ - shift speed gradient, $\mathrm{s}^{-1}$.

Losses at the thermal processing were determined by the weighing method by the difference of masses, taking into account evaporation losses norms by the formula:

$$
B_{m}=\left(1-\frac{m_{1}}{m_{2}}\right) \cdot 100 \% \text {, }
$$

where $m_{1}$ - mass of the semi-product after the thermal processing, g; $m_{2}$ - mass of the semi-product before the thermal processing.

The water activity of model samples of the milk-protein mashes for semi-products was determined by the device Rotronic, Hygro Palm AW modification (Rotronic AG, Switzerland). The measuring diapason is following: $0 . .1 a_{w}$, sample temperature $5 . .50{ }^{\circ} \mathrm{C}$, distinctness $\pm 0.01 a_{w}, \pm 0.1{ }^{\circ} \mathrm{C}$.

The images of Rotroni of Hygro Palm AW modification are presented on Fig. 1.

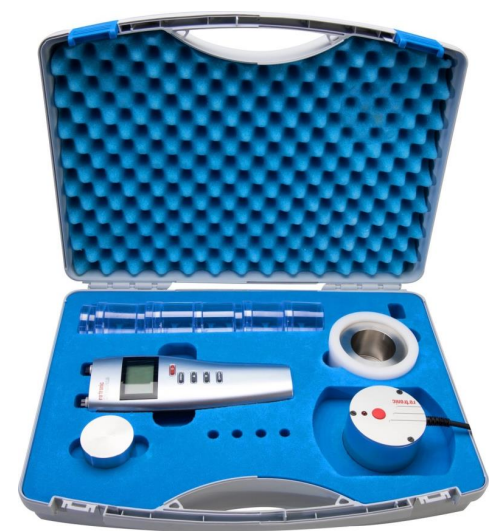

Fig. 1. Analyzer of water activity Rotronic of HygroPalm AW modification 
The analyzer of water activity consists of a measuring block, station HC2-AW, case for transportation and storage, calibrating solutions, plastic cups for samples [21].

The principle of action of the analyzer is in using a dielectric fixer of moisture for determining the water activity. A porous polymer is placed between porous electrodes of the hermetized chamber. Its electric properties change depending on the relative humidity of the chamber. Electrodes give a signal, based on the relative humidity in the closed chamber. It is transformed by the software and reflected on the device screen as a value of the water activity. The measuring cycle lasts from 3 to $5 \mathrm{~min}$. The air relative humidity in the chamber at balance equals to the water activity value of the experimental sample. The water activity value is calculated up to the third symbol after the point.

\section{Research results}

Previous researches established the influence of white sugar and egg mélange on the titrated acidity, effective viscosity and water-retaining capacity of milk-protein mashes [22].

White sugar, egg mélange and PF, added to the protein base, don't intensify the course of processes and don't activate the acidity increase in milk-protein mashes. This parameter depends mainly on components and quality parameters of the base - fatless sour-milk cheese and doesn't exceed $150^{\circ} \mathrm{T}$.

It has been established, that egg mélange and white sugar decrease WRC and effective viscosity of milk-protein mashes for semi-products, and PF increases these parameters. The model sample that includes $10 \%$ of egg mélange and $2.0 \%$ of PF has WRC, maximally approximated to the control and effective viscosity, increased by $181.67 \pm 2.20 \mathrm{~Pa} \cdot \mathrm{s}$. At adding only $2.0 \%$ of PF to sour-milk cheese, there is observed the excessive densification of the model samples and the effective viscosity value deviates from the control one by $257.7 \pm 2.5 \mathrm{~Pa} \cdot \mathrm{s}$. The offered methods of effective viscosity determination objectively characterize the influence of egg mélange on mashes before thermal processing.

The ability of PF to absorb water is connected with a hydrophilicity degree and amount of present biopolymers, surface character and particles porosity, their sizes. «Potex» combines biopolymers with different water kindship in its composition.

The researches of the parameters of mashes, based on sour-milk cheese: effective viscosity, WRC and titrated acidity were conducted. The results of the common influence of all recipe components and control on the mash properties are presented in Table 3.

Table 3

The influence of the recipe components on the semi-products milk-protein mash properties

\begin{tabular}{cccc}
\hline No. of sample & Acidity, ${ }^{\circ} \mathbf{T}$ & WRC, $\%$ & Effective viscosity, Pa·s \\
\hline 1 (control) & $141.0 \pm 0.8$ & $62.0 \pm 0.2$ & $230.0 \pm 2.2$ \\
2 & $147.1 \pm 0.6$ & $59.1 \pm 0.1$ & $151.4 \pm 2.0$ \\
3 & $145.4 \pm 0.2$ & $60.8 \pm 0.3$ & $205.5 \pm 2.1$ \\
4 & $142.3 \pm 0.4$ & $62.5 \pm 0.2$ & $232.1 \pm 1.9$ \\
5 & $140.1 \pm 0.1$ & $64.2 \pm 0.1$ & $313.7 \pm 2.4$ \\
Note: & - values, approximated to the control sample.
\end{tabular}

The mass share of moisture in all experimental sample was within 54.0-62.0 \%, and titrated acidity rose to $147.1 \pm 0.6^{\circ} \mathrm{T}$ (in sample № 2), depending on the amount of fatless sour-milk cheese.

The mash, maximally approximated to the control (sample № 1) by indices of WRC and effective viscosity, includes $1.5 \%$ of PF and $10 \%$ of white sugar and egg mélange (sample № 4). For sample № 5 the effective viscosity index exceeds the control value by $83.7 \mathrm{~Pa} \cdot \mathrm{s}$. Effective viscosity deviations for samples № 2 and № 3 are from $78.4 \pm 0.9$ to $24.5 \pm 1.0 \mathrm{~Pa} \cdot \mathrm{s}$, and WRC - from $1.2 \%$ to $2.9 \%$ respectively. The used methods and obtained values give a possibility to determine the rational amount of the added recipe components in the mash at level: 1.5\% of PF, $78.5 \%$ of FLSMC and $10 \%$ of white sugar and egg mélange. The totality of indices of sample No. 4 proves a possibility of forming these semi-products by the mechanical way. 
The water activity index of the mashes was determined on the Rotronic device (according to Table 2). The model samples with different amounts of PF from $0.5 \%$ to $2.0 \%$ are characterized with the decrease of this index from 0.9623 to 0.9523 (sample № 5) comparing with the control $\left(a_{w}=0.9648\right)$. Such deviations in the values are conditioned by the increased water-retaining capacity of «Potex». The water activity has the applied importance and plays the role at elaborating methods and techniques, resulting in decreasing the level $a_{w}$.

For getting a semi-product, the mashes were directed to the thermal processing and qualimetric parameters were determined at stable conditions.

The results of determining mass losses of semi-products (samples according to Table 2) at the thermal processing at the different temperatures are presented in Table 4.

Table 4

The mass losses of semi-products at the thermal processing at the different temperatures

\begin{tabular}{ccc}
\hline \multirow{2}{*}{ No. of sample } & \multicolumn{1}{c}{ Mass losses (\%) of semi-products at temperatures } \\
\cline { 2 - 3 } & $\mathbf{1 8 5} \pm \mathbf{5}^{\circ} \mathbf{C}$ & $\mathbf{1 5 5}^{\circ} \mathbf{5}^{\circ} \mathbf{C}$ \\
\hline 1 (control) & $13.1 \pm 0.2$ & $12.5 \pm 0.2$ \\
2 & $11.2 \pm 0.3$ & $10.7 \pm 0.3$ \\
3 & $8.1 \pm 0.2$ & $7.4 \pm 0.2$ \\
4 & $7.7 \pm 0.1$ & $5.9 \pm 0.1$ \\
5 & $6.4 \pm 0.1$ & $4.4 \pm 0.1$
\end{tabular}

According to the results of the qualimetric studies, at replacing wheat flour by PF in $0.5-$ $2.0 \%$, mass losses of semi-products at temperatures $185 \pm 5{ }^{\circ} \mathrm{C}$ and $155 \pm 5{ }^{\circ} \mathrm{C}$ decrease in diapason $1.9-6.7 \%$. For the sample with adding $2.0 \%$ of PF there is observed the structure densification that is a limiting factor at the organoleptic level.

\section{Conclusions}

Determination of the effective viscosity, WRC and titrated acidity is effective for forecasting the use of DF - potato fiber instead of wheat flour and white sugar and egg mélange in the composition of mashes for semi-products.

The water activity $\left(a_{w}\right)$ determination on the analyzer, using the dielectric fixer of moisture, fixed a tendency to the parameter decrease at adding potato fiber from $0.5 \%$ to $2.0 \%$. Such approach is possible for specifying storage parameters of semi-products of food fiber at the classic temperatures.

Qualimetric parameters of semi-products, based on multi-component mashes, prove the positive influence of potato fiber with water-retaining properties for saving their mass at thermal processing. At adding the maximal amount of "Potex" $-2.0 \%$, mass losses at the frying and baking temperatures decrease and are $4.3 \pm 0.2 \%$ and $6.2 \pm 0.1 \%$ respectively.

An advantage of the elaborated method of determining characteristics of mashes with fiber on the milk-protein base is a possibility of its practical realization on the existent equipment for correcting qualimetric parameters of products. Its shortcoming is a necessity of specifying the maximal amount of other dietary fiber for preventing excessive densification of thermally processed semi-products.

Prospects of furthers studies in this direction are connected with studying technological properties of different bearers of dietary fiber for using in polycomponent milk products.

\section{References}

[1] DSTU 5052:2008. Napivfabrykaty iz syru kyslomolochnoho. Zahalni tekhnichni umovy (2010). Kyiv: Derzhspozhyvchstandart Ukrainy, 17.

[2] Mglintsa, A. I., Akimova, N. A., Dzyuba, G. N. et. al. (2010). Tehnologiya produktsii obshchestvennogo pitaniya. SanktPeterburg: Troitskiymost, 736. 
[3] Godwin, S., Maughan, C., Chambers, E. (2016). Food Safety: Recommendations for Determining Doneness in Consumer Egg Dish Recipes and Measurement of Endpoint Temperatures When Recipes Are Followed. Foods, 5 (4), 45. doi: https://doi.org/ 10.3390/foods5030045

[4] Manzoor, M. (2017). Effect of cooking temperature on some quality characteristic of Almond milk. International Journal of Agricultural and Life Sciences, 3 (1), 131-135. doi: https://doi.org/10.22573/spg.ijals.017.s12200077

[5] Bal-Prylypko, L. V. (2010). Tekhnolohiya zberihannia, konservuvannia ta pererobky miasa. Kyiv: KVITS, 468.

[6] Xie, F., Zhang, W., Lan, X., Gong, S., Wu, J., Wang, Z. (2017). Physicochemical properties and structural characteristics of soluble dietary fibers from yellow and purple fleshed potatoes by-product. International Journal of Food Properties, 20, S2939-S2949. doi: https://doi.org/10.1080/10942912.2017.1387557

[7] Silchuk, T., Nazar, M. (2016). Effect of potato fiber on the main processes in the dough. Scientific Works of NUFT, 22 (4), 199-204.

[8] Liu, X., Mu, T., Sun, H., Zhang, M., Chen, J. (2016). Influence of potato flour on dough rheological properties and quality of steamed bread. Journal of Integrative Agriculture, 15 (11), 2666-2676. doi: https://oi.org/10.1016/s2095-3119(16)61388-6

[9] Vysnovok sanitarno-epidemiolohichnoi ekspertyzy No. 05.03.02-03/61827 vid 07.10.2014 r., vyrobnyk - «LyckebyStarchAB» Shvetsiya.

[10] Pryanishnikov, V. V., Giro, T. M., Semikopenko, N. I. (2014). Proizvodstvo myasnyh polufabrikatov po innovatsionnym tehnologiyam. Molodoy ucheniy, 12, 95-98.

[11] Grek, O., Tymchuk, A., Tsygankov, S., Savchenko, O., Ovsiienko, K., Ochkolyas, O. (2019). Study of dietary fiber properties in dairy mixes containing modified fat compositions. Eastern-European Journal of Enterprise Technologies, 4 (11 (100)), 6-13. doi: https://doi.org/10.15587/1729-4061.2019.174302

[12] Kaack, K., Pedersen, L., Laerke, H. N., Meyer, A. (2006). New potato fibre for improvement of texture and colour of wheat bread. European Food Research and Technology, 224 (2), 199-207. doi: https://doi.org/10.1007/s00217-006-0301-5

[13] Yang, Y., Ma, S., Wang, X., Zheng, X. (2017). Modification and Application of Dietary Fiber in Foods. Journal of Chemistry, 2017, 1-8. doi: https://doi.org/10.1155/2017/9340427

[14] Tsygankov, S., Grek, O., Krasulya, O., Onopriichuk, O., Chubenko, L., Savchenko, O. et. al. (2018). Study into effect of food fibers on the fermentation process of whey. Eastern-European Journal of Enterprise Technologies, 1 (11 (91)), 56-62. doi: https://doi.org/10.15587/1729-4061.2018.120803

[15] Reshetnik, E. I., Maksimyuk, V. A., Emelianov, A. M. (2013). Multicomponent product technology improvement based on the dairy and grain raw material combination. Vestnik Krasnoyarskogo gosudarstvennogo agrarnogo universiteta, 11, $273-277$.

[16] Simeanu, D., Nistor, A., Avarvarei, B., Boisteanu, P. (2019). Chemical Composition and Nutritional Evaluation of Pasteurized Egg Melange. Revistade Chimie, 70 (4), 1390-1395.

[17] Hrek, O. V., Yushchenko, N. M., Osmak, T. H. et. al. (2012). Praktykum z tekhnolohiyi moloka ta molochnykh produktiv. Kyiv: NUKhT, 431.

[18] Onopriichuk, O. O., Grek, O. V., Pasichnyi, V. M., Pukhliak, A. G., Tymchuk, A. V. (2015). The modern approach to the development of cheese products technology. Prodovolcha industriya APK, 1, 25-29.

[19] Sikorsky, O., Myronyuk, O., Svidersky, V. (2015). Rheological Behavior of Montmorillonite Water Suspensions in the Presence of Surfactants. Chemistry \& Chemical Technology, 9 (2), 237-240. doi: https://doi.org/10.23939/chcht09.02.237

[20] Ahmed, J., Ptaszek, P., Basu, S. (2016). Advances in Food Rheology and Its Applications. Woodhead Publishing, 528. doi: https://doi.org/10.1016/c2014-0-04114-7

[21] Oborudovanie dlya predpriyatiy torgovli, obshchestvennogo pitaniya i pishchevoy promyshlennosti. Available at: http://www. oborud.info/product/jump.php?17009\&c $=690$

[22] Grek, O., Tymchuk, A., Chubenko, L., Ovsiienko, K. (2017). Research of quality indicators of curd products on basis of protein-herbal clots. Food and Environment Safety, Food and Environment Safety, XVI (4), 262-268. 